Note

\title{
SOMACLONAL VARIATION IN MICROPROPAGATED Heliconia Bihai cv. LOBSTER CLAW I PLANTLETS (Heliconiaceae)
}

\author{
Paulo Hercílio Viegas Rodrigues \\ UFRN/PPGGBM/BioCampo, Alameda das Mansões, 1178 - Candelária - 59067-00 - Natal, RN - Brasil. \\ Corresponding author <phrviegas@hotmail.com>
}

\begin{abstract}
The occurrence of somaclonal variation is described in various cultures of agronomic interest. Such variation can be of benefit in the development of new flower varieties. In this study, the occurrence of somaclonal variation in micropropagated changes of Heliconia bihai cv. Lobster Claw I was investigated. Stem apexes were introduced in MS culture media with the addition of $2.5 \mathrm{mg} \mathrm{L}^{-1}$ of benzylaminopure (BAP) and $500 \mathrm{mg} \mathrm{L}^{-1}$ of sodium cefotaxime. After selecting the apex stem, it was subcultivated in MS media and supplemented with $4.0 \mathrm{mg} \mathrm{L}^{-1}$ of BAP to induce side buds. To conduct the trial, 2,000 plants were selected and compared with plants originated from rhizomes. To calculate the percentage of the variants, the plant stature, the form and color of leaves and pseudostem were evaluated. The plants with buds presenting the same type of variation were considered as variants. The occurrence of three types of somaclonal variants was observed: Variation of the Chlorophyll in the Leaf, Low Stature Variant and Pseudostem and Petiole Color Variant, the latter with ornamental potential. The somaclonal variation rate for Heliconia bihai cv Lobster Claw I, under the proposed conditions, was $61.40 \%$.
\end{abstract}

Key words: tissue culture, flower growing, variability

\section{VARIAÇÃO SOMACLONAL EM MUDAS MICROPROPAGADAS DE HELICÔNIA, Heliconia Bihai cv. LOBSTER CLAW I (Heliconiaceae)}

\begin{abstract}
RESUMO: A ocorrência de variação somaclonal é descrita em diversas culturas de interesse agronômico. A floricultura pode beneficiar-se dessa variabilidade, com a obtenção de novas variedades. Nesse trabalho, estudou-se a ocorrência de variação somaclonal em mudas micropropagadas de Heliconia bihai cv. Lobster Claw I. Ápices caulinares foram introduzidos em meio de cultivo MS com adição de 2,5 $\mathrm{mg} \mathrm{L}^{-1}$ de benzilaminopurina (BAP) e $500 \mathrm{mg} \mathrm{L}^{-1}$ de cefotaxima sódica. Após a seleção do ápice caulinar, o explante foi subcultivado em meio MS suplementado com $4,0 \mathrm{mg} \mathrm{L}^{-1}$ de BAP para indução de brotações. Foram selecionadas, ao acaso, 2.000 mudas e comparadas com mudas originadas de rizomas, para compor o ensaio. No cálculo da porcentagem dos variantes avaliaram-se as características: estatura da planta, a forma e coloração das folhas e pseudocaule. Consideraram-se como variantes as plantas cujos perfilhos também mostravam o mesmo tipo de variação. Constatou-se a ocorrência de três tipos de variantes somaclonais, VCF (Variação da Clorofila na Folha), VPB (Variante de Porte Baixo) e VCPP (Variante da Coloração do Pseudocaule e Pecíolo), este último com potencial ornamental. A taxa de variação somaclonal para Heliconia bihai cv Lobster Claw I, nas condições propostas, foi de 61,40\%.

Palavras-chave: cultura de tecidos, floricultura, variabilidade
\end{abstract}

\section{INTRODUCTION}

Tropical flower agribusiness has been a rather important source of revenue in several countries, such as Colombia, Costa Rica, Honduras, Jamaica, the United States (Hawaii and Florida), Porto Rico, Suriname and Venezuela (Castro \& Graziano, 1997). In Brazil, the States of Rio de Janeiro, São Paulo, Santa
Catarina, Pernambuco, Amazonas, Ceará, Rio Grande do Norte and Alagoas, have been cultivating ornamental tropical plants at commercial scales (Castro, 1995).

Among the tropical flowers, heliconia is outstanding for its diversity in form, color, size and particularly, its durability. These characteristics give the Heliconiaceae family great potential in the ornamentals market, for composing valuable flower arrangements 
and bouquets that are greatly appreciated in the European market. The typical diversity of heliconias is also something that drives floriculture as a whole. This market, which is stimulated by novelties and fads, depends on the natural variety and different techniques that are developed in order to generate new products. The cultivation of plant tissues represents an important source of variety, producing different types of somaclonal variants that can be characterized as a true or epigenetic mutation. (Bouman \& De Klerk, 1997).

Studies of the factors that can influence the somaclonal variation rate in the micropropagation process, described by Scowcroft (1986) and George \& Sherrington (1984), have shown that the appearance of calluses at a certain stage of the micropropagation process is related to the somaclonal variation rate, as well as to prolonged in vitro cultivation periods. In fruit farming, banana growing presents innumerous results where somaclonal variants are obtained by different in vitro cultivation techniques. Authors such as, Reuveni et al. (1986), Krikorian et al. (1993); De Langue et al. (1996) and Santos \& Rodrigues (2004), describe different types of somaclonal variants, their performance in the field and the most probable causes for their development. Among the causes, the extremely high number of sub-cultures and elevated doses of growth regulators (cytokinins) during in vitro cultivation are highlighted.

Ornamental plants present significant results with somaclonal variation in azalea, sunflower and ornamental pineapple cultivars, among others (De Schepper et al., 2003; Encheva et al., 2003; Rodrigues et al., 2005). Such variability, which allows for a wide range of variants that would normally be discarded in other cultures, makes floriculture unique. The purpose of this study was to observe the occurrence of somaclonal variation in Heliconia bihai cv. Lobster Claw I plantlets, produced and destined for commercial growing.

\section{MATERIAL AND METHODS}

The material used as stock plant in the micropropagation process consisted of Heliconia bihai cv. Lobster Claw I rhizomes (lateral buds). Fifteen rhizomes were selected, and their external leaves were removed until they reached a size of approximately 5.0 $\mathrm{cm}$ in length by $2.5 \mathrm{~cm}$ in diameter. The rhizomes were soaked in a solution of water and sodium hypochlorite (2\% active chloride), at a 3:1 ratio, for approximately 25 minutes. After the antiseptic treatment, the rhizomes were washed (three times) with sterile distilled water inside a laminar flow chamber. When asepsis was completed, the stem apex, consisting of two to three leaves around the meristem and a small segment of rhizome, was isolated with the aid of tweezers and a scalpel.

The stem apexes were submitted to inoculation in semi-solid ( $2.0 \mathrm{~g} \mathrm{~L}^{-1}$ Gelrite), MS culture media (Murashige \& Skoog, 1962), supplemented with Morel vitamins (Morel \& Wetmore, 1951), saccharose (30.0 $\left.\mathrm{g} \mathrm{L}^{-1}\right)$, 6-benzyladenine (1.0 $\left.\mathrm{mg} \mathrm{L}^{-1} \mathrm{BAP}\right), \mathrm{pH}$ adjusted to 5.8 in addition to $500 \mathrm{mg} \mathrm{L}^{-1}$ of sodium cefotaxime, for control of endophytes (Rodrigues, 2005). The explants were incubated at a mean temperature of $26^{\circ} \mathrm{C}$ and a photoperiod of 16 hours of light. Of the 15 inoculated stem apexes, ten oxidized in five days, two in ten days after inoculation, and after 30 days, the most vigorous of the three surviving apexes was selected as matrix for the trial.

The explant subcultures for forming plantlets began with their transfer to the semi-solid $\left(2.0 \mathrm{~g} \mathrm{~L}^{-1}\right.$ Gelrite) culture media with MS salts and Morel vitamins, saccharose $\left(30.0 \mathrm{~g} \mathrm{~L}^{-1}\right)$ supplemented with 4.0 $\mathrm{mg} \mathrm{L}^{-1}$ of BAP, for lateral bud induction under the same temperature and photoperiod conditions mentioned above. The explant was subcultivated every four weeks until the approximate number of 4,000 plantlets was attained, which occurred after 18 subcultures.

To compose the trial, a random selection was made of 2,000 plantlets having 7.0 to $10.0 \mathrm{~cm}$ in length, which were climatized in a sterile substrate, $80 \%$ shade and $80 \%$ relative humidity during ten days. Plantlets were then transferred to 24-cell plastic trays containing the same substrate, with an additional $2 \%$ of the 10-10-10 formula, and remained in the vivarium under $50 \%$ shade, until they were approximately 30.0 $\mathrm{cm}$ long. In comparison with the micropropagated material, 200 rhizomes of the same variety not originating from tissue culture were used, obtained by the traditional method and cultivated in $11 \times 14 \mathrm{~cm}$ plastic bags, and with a mean size of $30.0 \mathrm{~cm}$, suitable for planting.

Once the plantlets were obtained, the trial was planted in an experimental area, located in the city of Gonçalo do Amarante - State of Rio Grande do Norte,

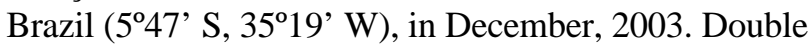
row planting was adopted, using $1.5 \times 1.5 \mathrm{~m}$ spacing between rows and plants, and $2.0 \mathrm{~m}$ between the double rows. The trial received regular cultivation treatments for the culture, and micro-spray irrigation. The control was randomly distributed among ten rows of 20 plants, side by side with the micropropagated plantlets, planted during the same period.

Assessments were made monthly and consisted of observing each plant individually, with the purpose of identifying some type of morphologic variation. 
During assessment, variant morphologic characteristics were observed with regard to variation in the coloring and shape of the leaf, pseudostem and inflorescence, plant stature and the interaction among these characteristics. The plants whose buds also exhibited the same type of variation were considered variant. The collected data were compared with the control and quantified in percentages.

\section{RESULTS AND DISCUSSION}

Flowering, both in the micropropagated and control material, began seven months after planting and assessments were made until February, 2005. At the end of the evaluations, the observed morphologic variations were quantified (Table 1), and described as follows:

VCL (Variation of Chlorophyll in the Leaf): This variation of chlorophyll in the leaf, or "leaf variegation", was also observed in other cultures (banana, pineapple) with different degrees of intensity (Zaffari et al., 1998; Soneji et al., 2002). In general, this is an epigenetic variation, which characteristic tends to disappear as the plant develops (Kaeppler et al., 2000). In the trial, variegations were observed in the foliage up to the fourth leaf issued. As from the fifth leaf, the variegation became unnoticeable, and was not detected until the end of the plant cycle, which produced inflorescence with normal characteristics. It was noted that this characteristic was observed in all descendants, including samples planted in pots (Figure 1A).

LSV (Low Stature Variant): Low stature or "Dwarf", frequently observed in somaclonal variants of banana trees (Israeli et al., 1996), is characterized by reduced plant size and unsatisfactory production. In this trial, in addition to low stature, super budding and general discoloration of the shoot were observed, and no phytopathogen or nutritional deficiency that could mark the results was diagnosed. At the end of the assessments, the shoot presented a height of $0.60 \mathrm{~m}$, against $3.50 \mathrm{~m}$ of the control, and absence of flower production (Figure 1B).
VPPC (Variant of Pseudostem and Petiole Coloring): This type of variation, also partly observed in banana culture, is characterized by the form and geometry in which this variation occurs. In banana trees, it varies in color from black to wine, and occurs in random areas of the pseudostem, while not occurring in the foliar petiole (Rodrigues et al., 1998). For this variety of Heliconia bihai, the reddish tone of the pseudostem appears in the form of equidistant spiral striae that extend up to the foliar petiole, giving an exotic appearance to this floral spike (Figure 1C). Absence of this characteristic is noted on the floral spike of the control (Figure 1D).

One of the causes of somaclonal variation occurrence is the excessive number of sub-cultures, which may vary within the same species, as is the case of banana trees and strawberries (Nehra et al., 1994; Karp, 1994), and among different species, each with its limit of subcultures. For this Heliconia bihai culti-
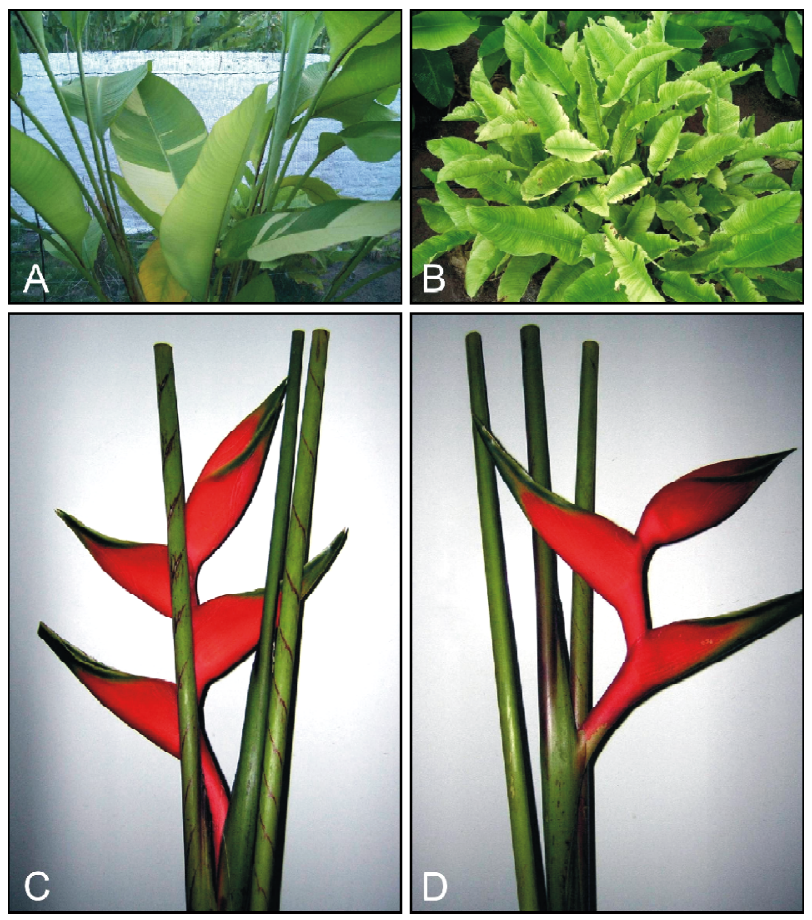

Figure 1 - Heliconia bihai cv Lobster Claw I (A) VCL = variation of chlorophyll in Leaf; (B) $L S V=$ low stature variant; (C) $V P P C=$ variant of pseudostem and petiole coloring; (D) Normal floral spike.

Table 1 - Somaclonal variants found in Heliconia bihai cv Lobster Claw I in the field trial in the city of São Gonçalo do Amarante (RN), Brazil, 2005.

\begin{tabular}{|c|c|c|c|c|c|c|}
\hline \multirow[t]{2}{*}{ Treatment } & \multicolumn{3}{|c|}{ Plants Observed } & \multicolumn{3}{|c|}{ Types of Somaclonal Variants } \\
\hline & Total & Normal & Variants & VCL & LSV & VPPC \\
\hline & $\cdots$ & ---U & 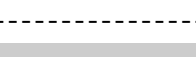 & -- & $\cdots--$ & $\cdots$ \\
\hline Control & 200 & $200(100)$ & --- & --- & --- & --- \\
\hline Micropropagated Plantlets & 2,000 & $772(38.6)$ & $1,228(61.4)$ & $3(0.15)$ & $2(0.1)$ & $1,223(61.15)$ \\
\hline
\end{tabular}

$V C L=$ variation of chlorophyll in Leaf; $L S V=$ low stature variant; $V P P C=$ variant of pseudostem and petiole coloring. 
var, the somaclonal variation rate was $61.40 \%$. This rate, considered high, exceeds the variability limit considered as acceptable by the market, which is approximately $5 \%$. This variability occurred after eighteen sub-cultures, which indicates that for this species or heliconia cultivar, the maximum limit number of subcultures for maintaining the genetic uniformity of the micropropagated plantlet was exceeded.

Normally genetic variability in cultures favored by the micropropagation technique is undesirable for rural producers. Cases such as those of some farmers in the city of Paranapanema, State of São Paulo, Brazil (232' S; 48 43' W), presented by Rodrigues (1996), observed somaclonal variation rates in banana cv. Grande Naine of up to $80 \%$, which have caused serious losses to farmers.

The data obtained in the present trial demonstrated the importance of assessing plantlets produced by tissue culture techniques and destined for use by farmers, under field conditions. During the acclimatization and vivarium phases, no variegation-type or foliar deformation anomalies were observed in the plantlets, which could serve as an indicator for the pre-selection of possible variants, as is the case with dates and bananas (Kunert et al., 2001; Sahijram et al., 2003). In this case, the Heliconia bihai, one of the most commercialized tropical ornamental plants in the world, was benefited by this specific type of variability, and VPPC can be considered a new product in the ornamentation market. Therefore, despite the need for molecular analysis to qualify these variants, somaclonal variation is a promising tool for obtaining genetic variability, mainly when used in floriculture and ornamentation.

\section{ACKNOWLEDGEMENTS}

To BioCampo Ltda. for its support in producing plantlets and conducting the culture, and to $\mathrm{CNPq}$ (RHAE Innovation Project).

\section{REFERENCES}

BOUMAN, H.; DE KLERK, G.J. Somaclonal variation. In: GENEVE, R.L.; PREECE, J.E.; MERKLE, S.A. Biotechnology of ornamental plants. Wallingford: CABI, 1997. p.165-183.

CASTRO, C.E.F.; GRAZIANO, T.T. Espécies do gênero Heliconia (Heliconiaceae) no Brasil. Revista Brasileira de Horticultura Ornamental, v.3, p.15-28, 1997.

CASTRO, C.E.F. Helicônias para exportação: aspectos técnicos da produção. Brasília: MAARA-SDR-FRUPEX/ISPI, 1995, 58p.

ENCHEVA, J.; KÖHLER, H.; FRIEDT, W.; TSVETKOVA, F.; IVANOV, P.; ENCHEVA, V.; SHINDROVA, P. Field evaluation of somaclonal variation in sunflower (Helianthus annuus L) and its application for crop improvement. Euphityca, v.130, p.167-175, 2003.

GEORGE, E.F.; SHERRINGTON, P.D. Plant propagation by tissue culture. In: EXEGETICS. Handbook and directory of commercial laboratories. London: Exegetics, 1984. p.51-78.
ISRAELI, Y.; BEN-BASSAT, D.; REUVENI, O. Selection of stable banana clones which do not produce dwarf somaclonal variants during in vitro culture. Scientia Horticulturae, v.67, p.197205, 1996.

KAEPPLER, S.M.; KAEPPLER, H.F.; RHEE, Y. Epigenetic aspects of somaclonal variation in plants. Plant Molecular Biology, v.43, p. 179-188, 2000.

KARP, A. Origins, causes and uses of variation in plant tissue cultures. Plant Cell Tissue and Organ Culture, v.7, p.139-151, 1994.

KRIKORIAN, A.D.; IRRIZARRY, H.; CRONAUER, S.; RIVERA, E. Clonal fidelity and variation in plantain (Musa AAB) regenerated from vegetative stem and floral axis tips in vitro. Annals of Botany, v.71, p.519-535, 1993.

KUNERT, K.J.; BAAZIZ, M.; CULLIS, C.A. Techniques for determination of true-to-type date palm (Phoenix dactylifera 1.) plants: a literature review. Emirates Journal of Agricultural Sciences, v.15, p.1-16, 2001.

MOREL, G.; WETMORE, R.H. Tissue culture of monocotyledons. American Journal of Botany, v.38, p.138-140, 1951.

MURASHIGE, T.; SKOOG, F. A revised medium for rapid growth and bioassays with tabacco tissue cultures. Plant Physiology, v.15, p.473-497, 1962.

NEHRA, N.S.; KARTHA, K.K.; STUSHNOFF, C.; GILES, K.L. Effect of in vitro propagation methods on field performance of 2 strawberry cultivars. Euphytica, v.76, p.107-115, 1994.

REUVENI, O.; ISRAELI, Y.; DEGANI, H.; ESHDAT, Y. Genetic variability in banana plants multiplied via in vitro techniques. In: INTERNATIONAL BOARD FOR PLANT GENETIC RESOURCES MEETING, Rome, 1986. Resumos. Rome: IBPGR, 1986. p.36.

RODRIGUES, P.H.V. Efeito do número de subcultivos na ocorrência de variação somaclonal em mudas de bananeira micropropagadas dos cultivares nanicão e grande naine. Piracicaba: USP/CENA, 1996. 104p. Tese (Doutorado).

RODRIGUES, P.H.V. In vitro establishment of Heliconia rauliniana (Heliconiaceae). Scientia Agrícola, v.62, p.69-71, 2005.

RODRIGUES, P.H.V.; TULMANN NETO, A.; CASSIERI NETO, P.; MENDES, B.M.J. Influência do número de subcultivos na ocorrência de variação somaclonal em mudas de bananeira cv. Nanicão, no Vale do Ribeira - SP. Revista Brasileira de Fruticultura, v.20, p.74-79, 1998.

RODRIGUES, P.H.V.; FARIA, O.A.; DUTRA, M.F.B.; LIMA, A.M.L.P. Variação somaclonal em mudas micropropagadas de abacaxi ornamental (Bromeliaceae; Ananas bracteatus, var. striatus). Horticultura Brasileira, v.23, p.581, 2005.

SANTOS, C.C.C.; RODRIGUES, P.H.V. Variação somaclonal em mudas micropropagadas de bananeira, cultivar Pacovan, Bragantia, v.63, p.201-205, 2004

SAHIJRAM, L.; SONEJI, J.R.; BOLLAMMA, K.T. Analyzing somaclonal variation in micropropagated bananas (Musa spp.). In Vitro Cellular \& Developmental Biology-Plant, v.39, p.551-556, 2003.

SCOWCROFT, W.R. Genetic variability in tissue culture, impact on germplasm conservation and utilization. In: INTERNATIONAL BOARD FOR PLANT GENETIC RESOURCES MEETING, Rome, 1986. Resumos. Rome: IBPGR, 1986. p.41.

SCHEPPER, S.; DEBERGH, P.; BOCKSTAELE, E. van; DE LOOSE, M.; GERATS, A.; DEPICKER, A. Genetic and epigenetic aspects of somaclonal variation: flower colour bud sports in azalea, a case study. South African Journal of Botany, v.69, p.117-128, 2003.

SONEJI, J.R.; RAO, P.S.; MHATRE, M. Somaclonal variation in micropropagated dormant axillary buds of pineapple (Ananas comosus L., Merr.). Journal of Horticultural Science \& Biotechnology, v.77, p.28-32, 2002.

ZAFFARI, G.R.; PERES, L.E.P.; KERBAUY, G.B. Endogenous levels of cytokinins, indoleacetic acid, abscisic acid, and pigments in variegated somaclones of micropropagated banana leaves. Journal of Plant Growth Regulator, v.17, p.59-61, 1998.

Received March 05, 2007

Accepted March 13, 2008 